\title{
Cognitive functions and success in choreography skills' formation in secondary school age dancers
}

\author{
Korobeynikov G.V. ${ }^{1}$, Myshko V.V. ${ }^{2}$, Pastukhova V.A. ${ }^{1}$, Smoliar I.I. ${ }^{1}$ \\ ${ }^{1}$ National University of Physical Education and Sport of Ukraine \\ ${ }^{2}$ Uzhhorod National University
}

\begin{abstract}
Purpose:

to find connection between level of cognitive functions realization and successfulness of choreography functions formation in junior dancers.

Material: $\quad 32$ dancers (16 pair) were tested. Sportsmen's age was 15-16 years; qualification - from first category to candidate master of sports of Ukraine.

Results: it was found that functional state of successful sportsmen is manifested in nervous system's high workability, emotional optimization and feeling of personal comfort. Success of junior dancers is conditioned by high cognitive functions: attention, quickness of visual perception, high operative and logic thinking, when processing verbal information. Besides, it is conditioned by quickness of responding to irritator in non-verbal cognitive test. Attention worsens in successful dancers at the account of increase of information processing quickness. It reflects in weakening of effectiveness and stability of test for non-verbal information processing fulfillment.

Conclusions: $\quad$ successfulness of technical skillfulness formation depends on cognitive functions and opportunities for their realization: high attention, quickness of visual perception and operative and logic thinking in processing of verbal (non-verbal) information and taking decisions.

Keywords: cognitive functions, attention, perception, thinking, successfulness, dancers.
\end{abstract}

\section{Introduction}

Sport dancing is rather a ne kind of sports and many directions of training and competition activity have been still remaining unstudied. Scientists note that there is a problem of rather subjective moments in competitions assessments [1, 2, 6, 11]. Modern ball dance is a synthesis of art and sport. At present stage of sport dancing history ball dancing is more sport than art.

The process of elite sportsmen's training is realized at level of extreme physical and psychic forces. It conditions demand in profound study of scientific ideas about functional mechanisms of functional reserves' improvement in adaption to increasing physical loads [10, 12]. Rather important is the fact that in elite sportsmen's training results' improvement is observed under loads, oriented on maximal development of genetically determined features [3, 5, 16].

Sport dances' structure includes art, choreography and sport component. Sport dancing popularity is explained by aesthetic character of it and sportsmen's performing maximally difficult motor skills. As a kind of sports sport daces require high coordination skills. Such skills are demonstrated in conditions of musical accompaniment. That is why sport dances open different human abilities (including cognitive). Among psychological and physiological characteristics, ensuring sport dancing effectiveness, there are cognitive functions [13, 15]. They are responsible for training process and directly participate in port activity formation and realization [20].

In evolution human organism formed nervous system's mechanisms, ensuring personality's optimal choice of functioning. They can include individual typological

\footnotetext{
(C) Korobeynikov G.V., Myshko V.V., Pastukhova V.A.

Smoliar I.I., 2017
}

doi:10.15561/18189172.2017.0103 features and cognitive functions, which, to large extent, are genetically inherited. Cognitive functions are under influence of phenotype factors (sport functioning) $[8,9$, $17,18]$

In modern scientific literature there are practically no data, relating to the mentioned problem. This problem is closely connected with system of different irritators' perception in realization of sport dances successful results. Traditionally cognitive functions include characteristics of external information perception, attention, memory and thinking [4, 14]. In sport dances fulfillment of difficult elements, synchronizing with musical accompaniment and motor skills' realization require involvement of all cognitive sphere.

Recent years there have been appeared rather a lot of scientific works on organization of training process, physical training and sportsmanship in sport dancing. But there are practically no researches on connection between cognitive functions and successfulness of 15-16 years' age dancers [7].

Hypothesis: it I assumed that there is certain connection between cognitive functions' level and effectiveness of choreographic skills' formation in sport dancing.

The purpose of the works is to find connection between level of cognitive functions realization and successfulness of choreography functions formation in junior dancers. .

\section{Material and methods}

Participants: 32 qualified junior sportsmen - dancers participated in the research (16 pairs). The sportsmen's age was 15-16 years that corresponds to category "Juniors" in sport dancing. The sportsmen's qualification was from $1^{\text {st }}$ category to candidate master of sports of Ukraine.

Every dancer was assessed by five criteria of 
successfulness (10 points' system for each criterion) for further distribution in groups of more or less successful sportsmen.

The first group included dancers with the highest successfulness by special tests- 12 persons ( $>71$ points), the second group included sportsmen with less successfulness -20 persons ( $<70$ points).

Organization of the research: testing was conducted in the first half of day without physical loads. Conditions for psycho-physiological resting net the following requirements: standardization of external conditions and testing procedure, creation of psychological climate and motivation of the tested. All sportsmen gave consent for testing and for usage of testing results in scientific purposes, in compliance with recommendations of ethic committee of bio-medical researches [19].

Five special criteria for high technical skillfulness composed of referees' criteria for dancers' performance skillfulness, determining successfulness of competition program. They are:

1. Temp and main rhythm (“musicality” - assessment of musicality of cadency) dancing in time means that every step is finished not before and not after but exactly at certain count. Observation of main rhythm mean that step is made during proper time (for example slowly or quickly) and correct correlation between quick and slow steps is observed.

2. Lines of bodies (correct elegant lines of pair, corresponding to the character of competition dance). Referee assesses: lines of arms, back; lines of shoulders, hips; lines of legs and neck; left and right side lines. Marks for every line are synonymous.

3. Movements ("dynamic" - fulfillment of figures; movement, corresponding to the character of dance). Referee shall determine the following: movement's correspondence to the character of dance; lifting and descending, swing and balance of pair. Excessive swing brings to marks' improvement only if movements are controlled and balance is kept. In dances of Latin America it is necessary to assess plasticity of body work, which is characteristic for every dance.

4. Works of foot means "technique" - exact fulfillment of figures: direction of feet movements in respect to torso in different positions. Referee shall determine correctness of all foot area work (toes, heels, positions and movements; closeness of feet, expressiveness and control of legs' movements).

5. Presentation means showing of every dance character, behavior on parquet.

For cognitive functions study we used the following methodic approaches: test for perception of verbal irritators, which showed efficiency, quickness, accuracy and effectiveness of tasks; test "comparison of numbers" with indicators: effectiveness, latency of solution, accuracy and stability.

For determination of psychic condition of dancers with different successfulness we used color Luscher's test. It permits to determine sportsman's psychic state (by color preferred by the tested): workability, fatigue, anxiety, deviation from autogenic norm, eccentricity, concentricity, heteronomy, autonomy and vegetative coefficient.

Statistical analysis: the received data were processed with MS Excel and «Statistica 6.0» applied programs. As far as indicators were not subjected to the law of normal distribution, for determination of statistically significant difference between samples we used Wilcoxon signed rank sums test. For demonstration of data distribution we used inter-quartile range, which pointed at first $(25 \%$ percentile) and third quartile (75\%).

Table 1. Characteristics of psycho-physiological state by Luscher's test in dancers with different successfulness (median, top and bottom quartiles)

\begin{tabular}{lll}
\hline Indicators & More successful dancers $(\mathbf{n = 1 2 )}$ & $\begin{array}{l}\text { Less successful dancers } \\
(\mathbf{n = 2 0})\end{array}$ \\
\hline Workability, conv.un. & 12.00 & $7.50^{*}$ \\
& $11.00 ; 14.00$ & $6.50 ; 10.00$ \\
Fatigue, conv.un. & 1.50 & 3.00 \\
& $1.00 ; 2.00$ & $2.00 ; 4.00$ \\
Anxiety, conv.un. & 0.5 & $2.00^{*}$ \\
& $0 ; 1.00$ & $1.00 ; 4.00$ \\
Deviation from autogenic norm, conv.un. & 12.00 & $17.00^{*}$ \\
Eccentricity, conv.un. & $6.00 ; 12.00$ & $14.00 ; 22.00$ \\
& 10.00 & $6,00^{*}$ \\
Concentricity, conv.un. & $9.00 ; 11.00$ & $4.00 ; 10.00$ \\
& 7.00 & 8.00 \\
Heteronomy, conv.un. & $6.00 ; 10.00$ & $7.00 ; 10.00$ \\
Autonomy, conv.un. & 7.00 & 6.00 \\
Vegetative coefficient, & $6.00 ; 9.00$ & $5.00 ; 8.00$ \\
& 10.00 & 9.50 \\
& $9.00 ; 12.00$ & $8.00 ; 11.00$ \\
\hline
\end{tabular}

Note: ${ }^{*}-p<0.05$, comparing with group of more successful dancers. 


\section{Results}

The dancers' psycho-physiological condition was determined by color Luscher's test; results are presented in table 1.

The received data showed nervous system highest workability in group of successful dancers. At the same time we found confident reduction of anxiety indicator that witnessed about optimal emotional state. In group of less successful dancers' anxiety state was noticed that witnessed about initial stage of stress.

Indicator of deviation from autogenic norm in less successful dancers' group is confidently higher that points at subjective discomfort. In other group we observed full comfort. Eccentricity (indicator, reflecting wish to release energy) is confidently higher in group of successful dancers. It points at the highest level of nervous system's strength, comparing with other group.

In group of successful dancers we observed confident increase of vegetative coefficient. It points at prevalence of nervous system's sympathetic part over para-sympathetic, comparing with group of less successful sportsmen.

The conducted researches of psycho-physiological conditions of dancers with different successfulness showed that nervous system workability, emotional state, subjective comfort and strength of nervous system are better in group of more successful sportsmen. Besides there is prevalence of nervous system's sympathetic part over para-sympathetic in more successful dancers.

In group of less successful dancers nervous system workability is confidently lower; there is increased anxiety and subjective discomfort with para-sympathetic part of nervous system's prevalence.

In table 2 we give results of cognitive test for verbal perception "recognition of regularities" by dancers with different successfulness.

Analysis of table 2 data shows that successful dancers have better indicators of accuracy and effectiveness in cognitive task's fulfillment. Test "recognition of regularities" is characterized by verbal tasks on recognition of coded word. In this test's fulfillment the main cognitive functions are: quickness of perception, operative and logic thinking, attention. Greater quantity of confidently higher absolute values of accuracy in group of more successful dancers points at higher attention and quickness of visual perception.

High effectiveness of successful dancers points at better logic and operative thinking under verbal irritators. Thus, sport dancing successfulness at junior level is conditioned by psychic functions of high attention, quickness of visual perception and increased operative and logic thinking, when processing verbal information in cognitive test.

In table 3 we present cognitive test results of processing non-verbal information "comparing numbers" by dancers with different successfulness.

Analysis of table 3 data shows confidently greater absolute indicators of effectiveness, latency and stability in less successful dancers. The received fact points at

Table 2. Indicators of cognitive test for verbal irritators "recognition of regularities" in dancers with different successfulness (median, top and bottom quartiles)

\begin{tabular}{lll}
\hline Indicators & More successful dancers $(\mathbf{n}=\mathbf{1 2})$ & Less successful dancers $(\mathbf{n}=\mathbf{2 0})$ \\
\hline \multirow{2}{*}{ Efficiency, conv. un. } & $18.00 ;$ & 17.00 \\
& $16.00 ; 20.00$ & $16.00 ; 20.00$ \\
Quickness, conv. un. & 3.50 & 3.58 \\
& $3.17 ; 4.36$ & $3.00 ; 4.00$ \\
Accuracy, conv. un. & 0.90 & $0.87 *$ \\
& $0.88 ; 0.96$ & $0.81 ; 0.91$ \\
Effectiveness, conv. un. & 60.00 & $49.29 *$ \\
& $56.00 ; 66.95$ & $46.81 ; 66.96$ \\
\hline
\end{tabular}

Note: ${ }^{*}-p<0.05$, comparing with group of more successful dancers.

Table 3. Indicators of "comparing numbers" test of dancers with different successfulness (median, top and bottom quartiles)

\begin{tabular}{lll}
\hline Indicators & More successful dancers $\mathbf{( n = 1 2 )}$ & Less successful dancers $(\mathbf{n}=\mathbf{2 0})$ \\
\hline \multirow{2}{*}{ Effectiveness, conv.un. } & 1104.60 & $1324.50^{*}$ \\
Latency, msec. & $1050.20 ; 1563.70$ & $1119.10 ; 1463.200$ \\
& 1055.40 & $1282.95^{*}$ \\
Accuracy, conv.un. & $1035.50 ; 1514.80$ & $1092.90 ; 1428.90$ \\
\multirow{2}{*}{ Stability, conv.un. } & 0.97 & 0.98 \\
& $0.96 ; 0.97$ & $0.95 ; 0.98$ \\
\hline
\end{tabular}

Note: ${ }^{*}$ - $p<0.05$, comparing with group of more successful dancers. 
better quickness of information perception and processing in group of successful dancers.

At the same time quickness of visual information perception by successful dancers negatively influences on effectiveness and stability of non-verbal cognitive task's fulfillment.

\section{Discussion}

Modern development of sport dancing shows significant influence of nervous system's individualtypological features on possibility of high sport result [7, 11].

However, the quality of motor skills formation depends on individual-typological characteristics of supreme nervous functioning $[4,17]$. It is known that nervous system's individual-typological properties are composed of neuro-dynamic and sensor-motor functions $[8,9,16,17]$. Neuro-dynamic and sensor-motor functions are genetically determined characteristics of supreme nervous functioning. It conditions sportsmen's ability for high coordination $[7,18]$.

In our previous works we found importance of characteristics of supreme nervous functioning individualtypological features. It also concerns functional mobility of dancers' nervous processes and connection of dancing successfulness with neuro-dynamic characteristics $[6,7]$.

At the same time effectiveness of technical actions in sport dances depends on sensor-motor chain of functional system and on cognitive functions of information perception, analysis and processing $[5,6,11,20]$.

Comparison of successful and not successful dancers by their special technical skills permitted to find higher workability in group of successful dancers, together with weakening of emotional anxiety. It points at optimal emotional state. Less successful dancer have higher emotional anxiety that points at initial stage of stress. Alongside with high workability of successful dancers we found their subjective feeling of comfort and signs of strong nervous system. Successful dancers have prevalence of sympathetic nervous system.

Thus, high successfulness in special technical elements' fulfillment is connected with adaptation resources' mobilization that manifests as activation of organism's sympathetic adrenaline system $[3,16]$. For optimization of junior dancers' training process it is necessary to consider the state and maximal level of their cognitive functions.

Basing on the above said we can conclude that successfulness in sport dances is conditioned by high activation of main cognitive functions: attention, perception and operative and logic thinking in processing verbal visual information $[1,6,7,13]$. As it is known in sport activity verbal intellect permits to consciously realize difficult motor skills. It acquires special importance in realization of dance programs [2, 13]. Verbal intellect permits to consciously perceive information from coach, directed at correction of technical elements' fulfillment.

Analysis of differences in non-verbal cognitive test results between groups of dancers with different successfulness showed quickness characteristics' prevalence in successful sportsmen. However, at the account of information processing quickness increase attention function of successful dancers worsens. It results in reduction of effectiveness and stability of test fulfillment. It is in agreement with previous researches [7]. Just concentration of attention gives additional mobilizing element for dancer's success in competition functioning.

In the process of the researches we proved that cognitive functions level of junior dancers influences on successfulness of special technical elements' realization. It is known that fulfillment of difficult technical elements in sport dances requires high coordination [2, 11, 12]. It is planned to concentrate further scientific researches on differentiation of technical training process, considering cognitive characteristics in sport dancing.

\section{Conclusions:}

In group of more successful dancers we found higher level of nervous system's physical, mental and psychoemotional workability; optimization of motional state, subjective comfort and strong nervous system.

Junior dancers' successfulness is conditioned by high level of main cognitive functions' activation: attention, quickness of visual perception, operative and logic thinking in processing verbal visual information.

In successful dancer we found prevalence of quickness characteristics of responding to irritator in nonverbal cognitive test. But at the account of increasing of information processing quickness attention worsens, that results in reduction of effectiveness and stability of this test's fulfillment.

\section{Acknowledgements}

The work has been fulfilled in compliance with combined plan of scientific research works in sphere of physical culture and sports for 2011 - 2015 by topic 2.23 "Preventing programs of elite sportsmen's neuropsycho-physiological support at final stages of many years' training" (state registration number 0111U007579).

\section{Conflict of interests}

The author declares that there is no conflict of interests. 


\section{References}

1. Artem'yeva G, Nechytailo M, Rozvitok koordinacijnikh zdibnostej ditej 9-11 rokiv za dopomogoiu tanciuval'nogo fitnesu $\mathrm{z}$ elementami indijs'kogo tanciu [Coordination abilities' training in 9-11 age children with the help of dancing fitness with elements of Hindu dances]. Slobozhans'kij naukovo-sportivnij visnik, 2014; 3(41):13-18. (in Ukrainian)

2. Demidova ON. Diferenciyniy pidhid na zaniattiah sportivnimi tanciamy z pidlitkamy 13 rokiv [A differentiated approach in the sporting dance studies with teenagers of 13 years old]. Pedagogics, psychology, medical-biological problems of physical training and sports, 2012; 4:44-49.

3. Zefirova EV, Kniazev VM, Rumianceva OL, Bulanov SV. $\mathrm{K}$ voprosu o psikhologicheskoj napriazhennosti v processe trenirovochnoj i sorevnovatel'noj deiatel'nosti [On the question of psychological tension in training and competition functioning]. NIU ITMO, 2013; 5; 148-152. (in Russian)

4. Iermakov SS. Psikhologicheskie testy $\mathrm{v}$ seti Internet i perspektivy ikh primeneniia $\mathrm{v}$ sportivnoj praktike [Psychological tests on the Internet and its application prospects in sports practice]. Fiziceskoe vospitanie studentov tvorcheskikh special'nostej, 2004; 3: 8-24. (in Russian)

5. Ilin EP. Psikhologiia sporta [Sports Psychology]. Sankt Petersburg; 2012. (in Russian)

6. Korobeinikova L, Stovba A, Cipenko F, Mickan T. Vzaiemozv'iazok mizh rivnem proiavu stresostijkosti ta kognitivnimi funkciiami $\mathrm{v}$ sportivnikh tanciakh [Interconnection of stress-resistance with cognitive functions in sport dancing]. Visnik Prikarpats'kogo universitetu, 2014; 19: 89-93. (in Ukrainian)

7. Korobeynikov GV, Myshko VV. Connection of supreme nervous functioning's neuro-dynamic characteristics with success of junior sportsmen in sports dances. Pedagogics, psychology, medical-biological problems of physical training and sports, 2016;4:17-22. doi:10.15561/18189172.2016.040 3

8. Makarenko NV, Lizogub V, Bezkopil'niy A. Formirovanie svojstv nejrodinamicheskikh funkcij u sportsmenov [Formation of neuro-dynamic functions' properties in sportsmen]. Nauka v olimpijskom sporte, 2005;2: 80-86. (in Russian)
9. Makarenko MV. Ontogenez psikhofiziologichnikh funkcij liudini [Ontogeny of human psycho-physiological functions]. Cherkassy: Vertikal; 2011. (in Ukrainian)

10.Platonov V.N. Sistema podgotovki sportsmenov v olimpijskom sporte [System of sportsmen's training in Olympic sports]. Kiev: Olympic Literature; 2015. (in Russian)

11. Sivickiy VA. Osobennosti sorevnovatel'noj deiatel'nosti $\mathrm{v}$ tanceval'nom sporte [Specific aspects of competition functioning in sport dancing]. Uchenye zapiski universiteta imeni P.F.Lesgafta,. 2012; 10(92): 146-150. (in Russian)

12.Soronovich IM, Chaikovsky EV, Pilevskaya V. Features of functional support of competitive activity in sports dance given the differences prepared by partners. Physical education of students, 2013;6:78-87. doi:10.6084/m9.figshare.840556

13.Bläsing B, Tenenbaum G, Schack T. The cognitive structure of movements in classical dance. Psychology of Sport and Exercise. 2009; 10(3): 350-360.

14.Eysenck MW. Fundamentals of cognition. Hove: Psychology Press; 2006.

15. Keeley TJ, Fox KR. The impact of physical activity and fitness on academic achievement and cognitive performance in children. International Review of Sport and Exercise Psychology. 2009; 2(2): 198-214.

16. Korobeynikov G, Korobeynikova L. Physical development and psychical function states in junior schoolchildren. Bratislava Medical Journal, 2003; 104(3): 125-129.

17.Korobeynikov G, Rossokha G, Koniaeva L, Medvedchuk K, Kulinich I. Psychophysiological diagnostics of functional states in sports medicine. Bratislava Medical Journal, 2006; 107(5): 205-209.

18. Korobeynikov G, Korobeynikova L, Mazmanian K, Jagello W. Diagnostics of psychophysiological states and motivation in elite athletes. Bratislava Medical Journal, 2011; 11: 637643.

19.Operational Guidelines for Ethics Committee that ReviwBiomedica Research. World Organization. Geneva. 2000.

20.Williams AM, Ericsson KA. Introduction to the theme issue: perception, cognition, action, and skilled performance. Journal of Motor Behavior, 2007; 9(5): 338-340.

\section{Information about the authors:}

Korobeynikov G.V.; http://orcid.org/0000-0001-5588-4825; george.65@mail.ru; National University of Physical Education and Sport of Ukraine; Fizkulture str. 1, Kiev, 03680, Ukraine.

MyshkoV.V.; http://orcid.org/0000-0003-0518-7751; Nikamyshko@gmail.com; Uzhhorod National University; Str. Podgornaya 46, Uzhgorod, 454080, Ukraine.

Pastukhova V.A.; http://orcid.org/0000-0002-0471-1331; pastuhova_v@ukr.net; National University of Physical Education and Sport of Ukraine; Fizkulture str. 1, Kiev, 03680, Ukraine.

Smoliar I.l.; http://orcid.org/0000-0001-7512-4305; rusik_s@mail.ru; National University of Physical Education and Sport of Ukraine; Fizkulture str. 1, Kiev, 03680, Ukraine.

Cite this article as: Korobeynikov GV, Myshko VV, Pastukhova VA. Smoliar II. Cognitive functions and success in choreography skills' formation in secondary school age dancers. Pedagogics, psychology, medical-biological problems of physical training and sports, 2017;1:18-22. doi:10.15561/18189172.2017.0103

The electronic version of this article is the complete one and can be found online at: http://www.sportpedagogy.org.ua/index.php/PPS/issue/archive

This is an Open Access article distributed under the terms of the Creative Commons Attribution License, which permits unrestricted use, distribution, and reproduction in any medium, provided the original work is properly cited (http://creativecommons.org/licenses/by/4.0/deed.en).

Received: 19.12.2016

Accepted: 05.01.2017; Published: 24.01.2017 